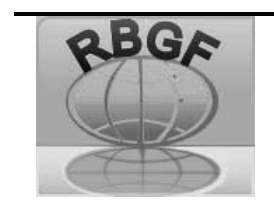

ISSN: 1984-2295

\section{Revista Brasileira de Geografia Física}

\title{
Lacandonia brasiliana A. Melo \& M. Alves (Triuridaceae), New Occurrence for the State of Ceará, Brazil ${ }^{1}$
}

\author{
Lucas Farias Pinheiro², Eliseu Marlônio Pereira de Lucena $^{3}$, Valéria da Silva Sampaio ${ }^{4}$, Isabela \\ Santiago Carneiro da Costa ${ }^{2}$
}

\begin{abstract}
${ }^{1}$ Part of the Master's research, performed by the first and guided by the second author, under the Postgraduate Program in Natural Sciences of the State University of Ceará, Fortaleza-CE, Brazil.

${ }^{2}$ Master student, Academic Master in Natural Sciences, State University of Ceará, Itaperi Campus, CEP 60.714-903, Fortaleza, CE. E-mail: lucas.pinheiro@aluno.uece.br - corresponding author; isabelasantiago819@gmail.com

${ }^{3}$ Post-Doctor, Associate Professor of the Biological Sciences Course and the Postgraduate Program in Natural Sciences, State University of Ceará, Itaperi Campus, CEP 60.714-903, Fortaleza, CE. E-mail: eliseu.lucena@uece.br

${ }^{4} \mathrm{PhD}$, Substitute Professor of the Biological Sciences Course, Dom Aureliano Matos Faculty of Philosophy, State University of Ceará, FAFIDAM Campus, CEP 62.930-000, Limoeiro do Norte, CE. E-mail: valeriasampaiobio@gmail.com
\end{abstract}

Artigo recebido em 04/12/2019 e aceito em 22/03/2020

\section{A B S T R A C T}

The Triuridaceae family is composed of saprophytic plants, chlorophylls, usually unbranched stems, leaves in alternate scales, bisexual or unisex racemous inflorescence, follicle or achene fruits. The species Lacandonia brasiliana A. Melo \& M. Alves was described as a new species at the beginning of this decade through its first occurrence in the state of Paraíba, Brazil and South America. The objective was to report the first occurrence of the species Lacandonia brasiliana to Ceará State, the second occurrence for Brazil and South America, contributing to the knowledge of its distribution. The species was collected through expeditions in Cerrado fragments, in the municipality of Viçosa do Ceará-CE, during May/2019, which had fertile structures for later taxonomic identification. The collected material was herborized and later deposited in the Herbarium Prisco Bezerra (EAC) of the Federal University of Ceará. Identification was based on identification keys, specialized bibliography, expert consultation, comparison with herbarium and standard specimens. The species is presented with description, taxonomic and ecological comments, distribution data and images. It is a small, non-branched, mycro-heterotrophous species found in a preserved area of Seasonal Semideciduous Forest, being the first record for a Cerrado phytophysiognomy area. It's concluded that the new occurrence of Lacadonia brasiliana for the State of Ceará highlights the importance of floristic surveys in Cerrado forest remnants, and it is possible to observe the expansion of its territorial distribution, degree of conservation and richness.

Keywords: Northeastern Brazil, Cerrado, Pandanales, saprophytes.

\section{Lacandonia brasiliana A. Melo \& M. Alves (Triuridaceae), Nova Ocorrência para o Estado do Ceará, Brasil}

\section{R E S U M O}

A família Triuridaceae é composta de plantas saprófitas, aclorofiladas, caule geralmente não ramificado, folhas em escamas alternas, inflorescência racemosa bissexuada ou unissexuada, frutos em folículo ou aquênio. A espécie Lacandonia brasiliana A. Melo \& M. Alves foi descrita como nova espécie no início desta década através de sua primeira ocorrência no Estado da Paraíba, no Brasil e na América do Sul. Objetivou-se relatar a primeira ocorrência da espécie Lacandonia brasiliana para o Estado do Ceará, a segunda ocorrência para o Brasil e para a América do Sul, contribuindo para o conhecimento da sua distribuição. A espécie foi coletada através de expedições em fragmentos de Cerrado, no município de Viçosa do Ceará-CE, durante o mês de maio/2019, a qual possuía estruturas férteis para a posterior identificação taxonômica. O material coletado foi herborizado e posteriormente depositado no Herbário Prisco Bezerra (EAC) da Universidade Federal do Ceará. A identificação ocorreu a partir de chaves de identificação, bibliografia especializada, consulta aos especialistas, comparação com espécimes de herbário e espécimes-tipo. A espécie é apresentada com descrição, comentários taxonômicos e ecológicos, dados de distribuição e imagens. Trata-se de uma espécie de pequeno porte, mico-heterótrofa, não ramificada, encontrada em área preservada de Floresta Estacional Semidecidual, sendo o primeiro registro para uma área de fitofisionomia do Cerrado. Conclui-se que a nova ocorrência da Lacadonia brasiliana para o Estado do Ceará evidencia a importância dos levantamentos florísticos em remanescentes florestais de Cerrado, sendo possível observar a expansão da sua distribuição territorial, o grau de conservação e a riqueza. Palavras-chave: Nordeste do Brasil, Cerrado, Pandanales, saprófita. 


\section{Introducion}

Triuridaceae, of the order Pandanales, comprises mycoheterotrophic achlorophyllous plants with unbranching (in the New World) stems distributed in the tropical and subtropical forests of the Old and New World, generally growing in the shadows of the forests, being almost imperceptible, reaching up to $40 \mathrm{~cm}$, making part of the monocot group. In addition to Triuridaceae, this order includes the families Cyclanthaceae, Pandanaceae and Velloziaceae (Maas \& Rübsamen, 1986; Mercks et al., 2013; Nuraliev, Cheek \& Beer, 2016; APG IV, 2016; Suetsugu et al., 2017) and is represented by nine genera with ca. 55 species (Christenhusz \& Byng, 2016; Govaerts, Maas-van de Kamer, \& Maas, 2016).

According to molecular data, the family Triuridaceae, includes 3 tribes, Kupeaeae (Kihansia and Kupea) which is endemic to Continental Africa; Sciaphileae (Andruris, Hyalisma, Sciaphila, Seychellaria and Soridium), which are part of the New and Old World, Sciphila being a paraphyletic group in relation to Seychellaria, however there is still no reorganization of this tribe. The first three genera of Sciaphileae stand out as the greatest diversity of the family with 36 species in total. The Triurideae tribe (Lacandonia, Peltophyllum, Triuridopsis and Triuris), is endemic to the Neotropics (Cheek, 2003; Mennes, Smets, Moses, \& Merckx, 2013; Tsukaya \& Suetsugu, 2014; Govaerts et al., 2016; Nuraliev et al., 2016).

Representatives of Triuridaceae are characterized by small, alternate leaves, reduced to scales, usually racemose inflorescences with small actinomorphic, bisexual, or unisexual flowers, superior ovary, dichlamydeous or monochlamydeous, and fruits of follicles or achenes (Mennes et al., 2013; Merckx et al., 2013; Souza \& Lorenzi, 2019).

The Triuridaceae family is found on decaying leaf litter in the interior of tropical forests, are often confused with fungi and poorly collected, for, apart from being small and achlorophyllous, have a very short reproductive cycle (Maas \& Rübsamen, 1986; Melo \& Alves, 2012; Mercks et al., 2013; Suetsugu et al., 2017; Sochor et al., 2018;).

In Brazil, Triuridaceae is represented by five genera (Lacandonia, Peltophyllum, Sciaphila, Soridium, and Triuris) and 13 species, with five of them Brazilian endemics Lacandonia brasiliana A. Melo \& M. Alves, Peltophyllum caudatum (Poulsen) R. Schmid \& M.D. Turner, Sciaphila oligantha Maas, Sciaphila schwackeana Johow, and Triuris alata Brade. Sciaphila is the most species-rich genus, with eight species in the Neotropics, of which seven occur in Brazil. Peltophyllum and Triuris have two species each, and Soridium and Lacandonia are monospecific (The Brazil Flora Group [BFG], 2018). Representatives of Triuridaceae are found predominantly in the North and Southeast regions of the country, in such phytogeographic domains as the Cerrado, and Amazonian and Atlantic Forests, with most of them restricted to Ombrophilous Forests, except for Lacandonia brasiliana A. Melo $\&$ M. Alves, found in Semidecidual Seasonal Forests.

Lacandonia brasiliana A. Melo \& M. Alves is an herbaceous monoecious plant, to $9 \mathrm{~cm}$ in height, with filiform roots, unbranched hyaline stems, leaves lacking, terminal (2!)4-6-flowered inflorescences, and apocarpic numerous ovaries. It was recently described from a fragment of the Atlantic Forest for the State of Paraíba, Northeastern Brazil (Melo \& Alves, 2012). It also presents tepals with subapical appendages, anther with slit-like opening, uniovulate carpels (Rudall, Alves, \& Sajo, 2016).

Studies concerning mycoheterotrophs plants are quite scarce, due to the lack of data for the identification and comparison of species, as well as few collections, including their morphological characters, for example data on staminate flowers that are crucial for correct identification (Tsukaya \& Okada, 2013; Tsukaya \& Suetsugu, 2014; Suetsugu et al., 2017).

Based on this, the objective of this work was to report the first occurrence of the species Lacandonia brasiliana A. Melo \& M. Alves in the state of Ceará, the second occurrence in Brazil and South America, contributing to the knowledge of its distribution, demonstrating that floristic surveys of areas still poorly collected are of great importance for the knowledge of local floras and regional biodiversity, in addition to providing new ecological and taxonomic data for the species.

\section{Materials and methods}

Specimens of Lacandonia brasiliana A. Melo \& M. Alves were collected during field work conducted in preserved fragments of the Cerrado vegetation (Figure 1a-b) in May of 2019.

The collected samples were processed following the standard techniques (Mori, Silva, Lisboa, \& Coradin, 1989) and deposited at the 
Prisco Bezerra Herbarium (EAC) of the Federal University of Ceará.

Specialized literature was used for species identification and description (Maas \& Rübsamen, 1986; Melo \& Alves, 2012; Rudall et al., 2016).

Morphological terminology followed Radford, Dickison, Massey and Bell (1974) and Gonçalves and Lorenzi (2011).

The distribution data was obtained from the NY, SP, and UFP herbarium collections (acronyms following Thiers, 2019) and the distribution map was generated using QGIS ver. 3.4.3.

Classification of vegetation followed the Brazilian Vegetation Technical Manual (Instituto Brasileiro de Geografia e Estatística [IBGE], 2012).

\section{Results and discussion}

Lacandonia brasiliana A. Melo \& M. Alves, Phytotaxa 40: 22-24, 2012 (Figure 2a-e).

Mycoheterotrophic monoecious herb, unbranched, to $6 \mathrm{~cm}$ high; stems filiform, hyaline, glabrous. Leaves lacking. Inflorescences racemose, terminal, (2!)4-6-flowered, bracteoles 1.25-1.5 × 0.5-0.75 mm, triangular,apex acute, with simple hyaline adpressed trichomes; Flowers $2-3.3 \mathrm{~mm}$ in diam., actinomorphous, bisexual; pedicels1.5-2 $\mathrm{mm}$ in the apical flowers, $2.5-4 \mathrm{~mm}$ in the basal, tepals 5-6, 1-1.75 × 1-1.25 mm, deltoid, yellow, brown in senescence, equal in size, with simple, hyaline, adpressed, sparse trichomes and a prominent central vein; ovaries numerous, apocarpic, papillose, surrounding the androecium, style $0.2-0.75 \mathrm{~mm}$ long; stamens 3 , tiny. Fruit achenes, $0.75-1.5 \mathrm{~mm}$ diam., yellow.

Material examined:- BRASIL. CEARÁ: Viçosa do Ceará, Serra das Flores, 23.V.2019, fl. and fr., E.M.P. Lucena et al. 666 (EAC).

Additional material examined:- BRASIL. PARAÍBA: Mamanguape, Reserva Biológica de Guaribas, 25.IX.2010, fl., A. Melo et al. 487 (NY, UFP); Trilha Cabeça de Boi, 21.VIII.2013, fl., A. Melo et al. 1195 (SP).

Lacandonia brasiliana A. Melo \& M. Alves is a mycoheterotrophic achlorophyllous plant, recognized by its small size, less than $10 \mathrm{~cm}$ in height, hyaline stems, and terminal yellowish flowers. The collected specimens showed presence of simple trichomes on their bracts, a new character for the species and other representatives of the achlorophyllous herbs occurring in Brazil, the feature not mentioned by Melo and Alves (2013).

The new occurrence of Lacandonia brasiliana A. Melo \& M. Alves for the State of Ceará represents a second such occurrence for Brazil and South America (Figure 3). Lacandonia brasiliana A. Melo \& M. Alves was found on the moist decaying leaf litter in protected areas of a Semideciduous Seasonal Forest, with fertile soil, at an altitude of $370 \mathrm{~m}$, with the average annual temperatures between 22 and $24^{\circ} \mathrm{C}$ and $1,349 \mathrm{~mm}$ of rainfall, typical of the Tropical Warm Subhumid climate (Instituto de Pesquisa e Estratégia Econômica do Ceará [IPECE], 2018).

Specimens of Lacandonia brasiliana A. Melo \& M. Alves were collected in May of 2019, both with flowers and fruit (Figure 2c-e). The forest fragment has the phytophysiognomy of a Cerrado forest, with the shrubby and tree vegetation forming a canopy, ranging in height from $40 \mathrm{~cm}$ to $12 \mathrm{~m}$, and including representatives of herbaceous and climbing plants (Ribeiro \& Walter, 1998). This is a first record of Lacandonia. brasiliana A. Melo \& M. Alves for the Brazilian Cerrado.

Guilherme et al. (2016) states that the collection of mycoheterotrophic plants in an environment of savanna vegetation, such as the Cerrado, is quite unusual, as the environmental characteristics aren't conducive, bringing subsidies to the understanding of the biogegraphy and diversity of this ecosystem, as seen that most collections are related to the woody flora.

With this record, it shows the importance of floristic studies in areas of Cerrado remnants, since this biome is quite degraded, mainly due to anthropogenic actions and the expansion of the agricultural frontier, thus being able to assist in the conservation and management of certain species (Andrella \& José Neto, 2017).

According to Strassburg et al. (2017) if by the year 2050 no preservation attitude occurs in the Cerrado, $31-34 \%$ of its remaining area will disappear. This will occur due to the increase in deforestation, causing damage to the harmony of the ecosystem, such as the decrease of native and 

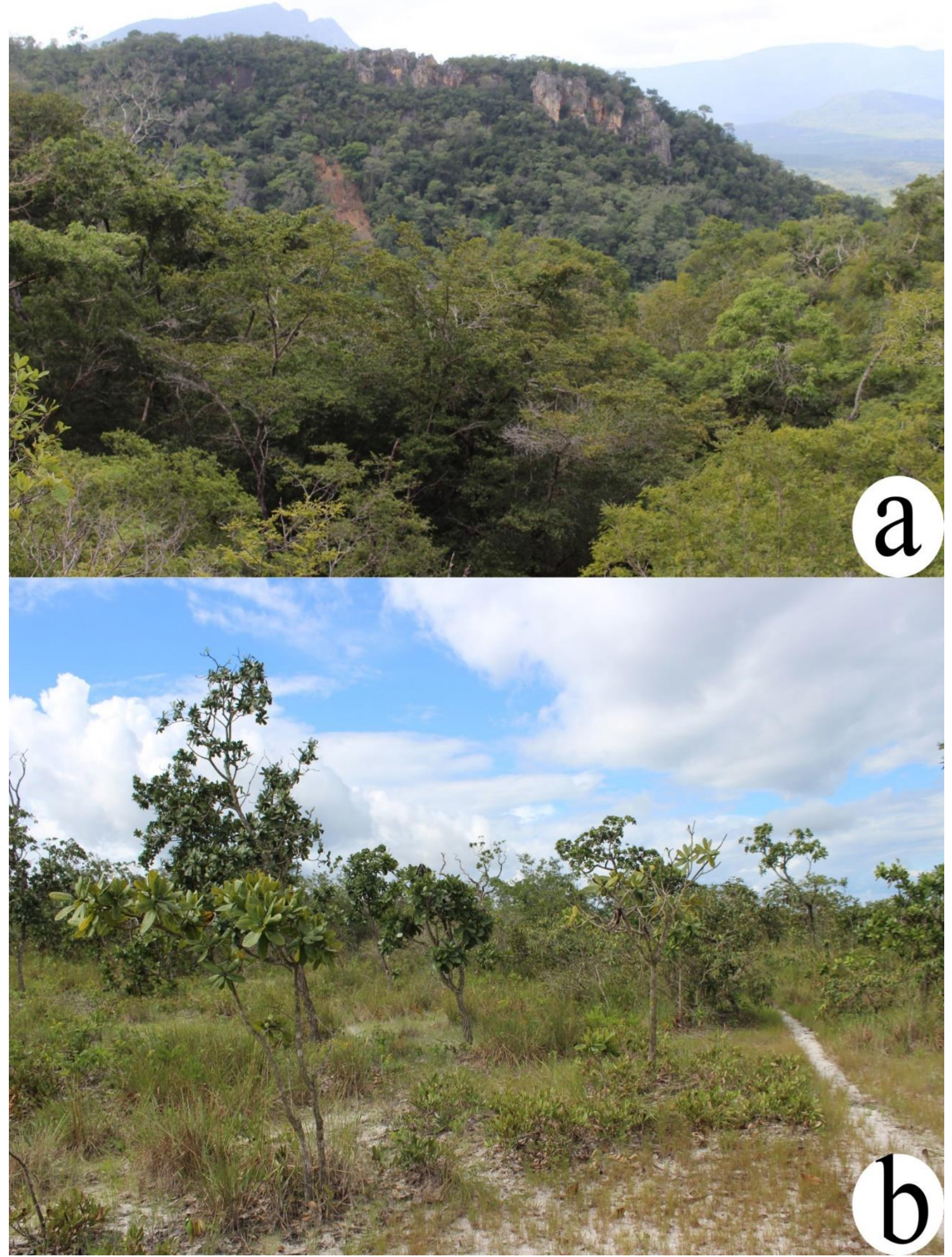

Figure 1. Fragment of Cerrado in the Serra das Flores, Viçosa do Ceará-CE. a. Serra das Flores profile. b. Phytophysiognomy of Cerrado stricto sensu in the Serra das Flores plateau. 

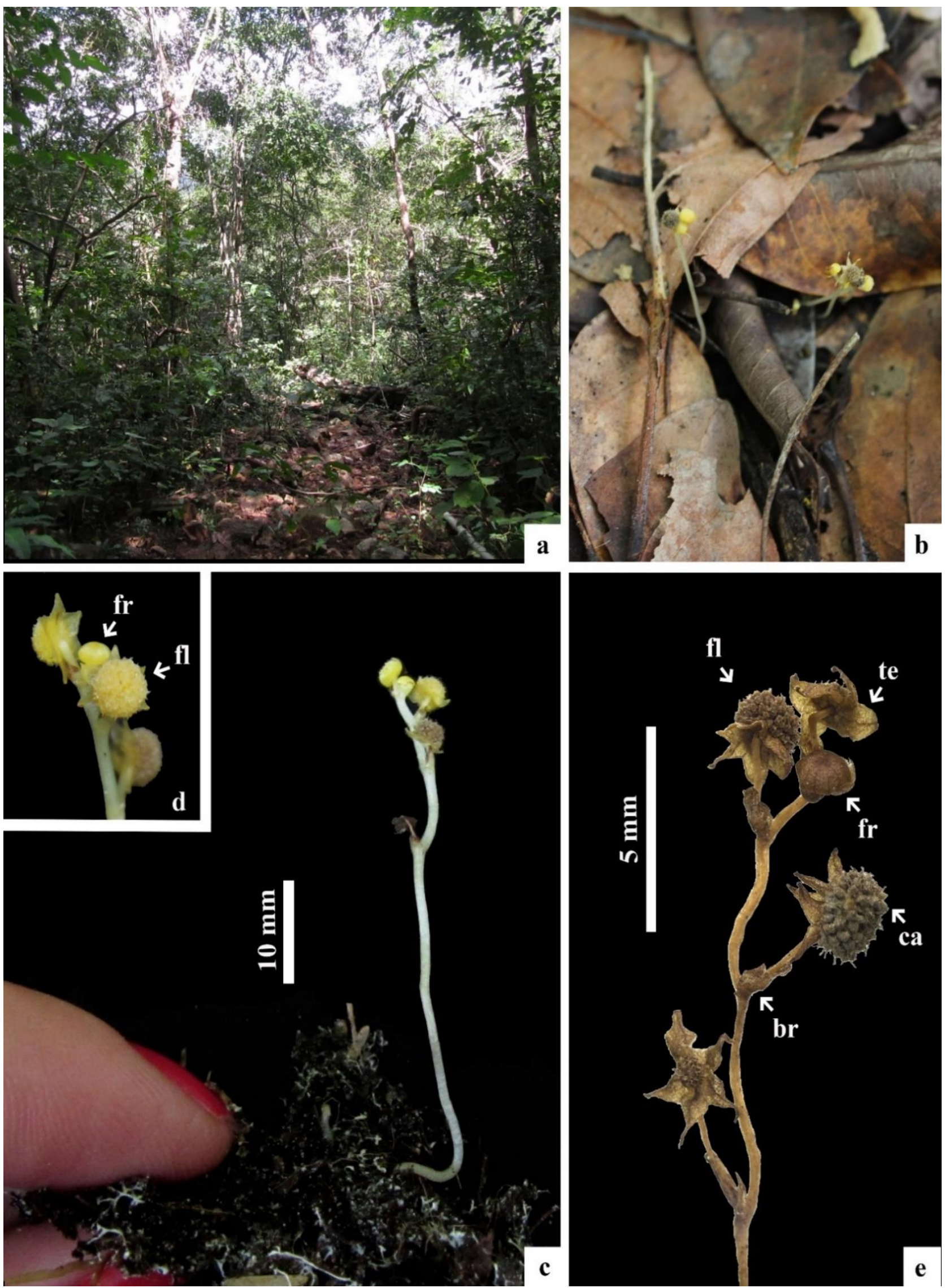

Figure 2. Seasonal Semideciduous Forest and Lacandonia brasiliana A. Melo \& M. Alves, Viçosa do CearáCE. a. Fragment of Seasonal Semideciduous Forest (Phytophysiognomy of Cerrado). b. Individuals of Lacandonia brasiliana A. Melo \& M. Alves in leaf litter. c. Height of Lacandonia brasiliana A. Melo \& M. Alves. d. Flowers (fl) and fruits (fr) in highlight. e. Herbarium specimen showing bracts (br), flowers (fl), tepals (te), carpels (ca), and fruit (fr) (a-e. Lucena et al. 666). 


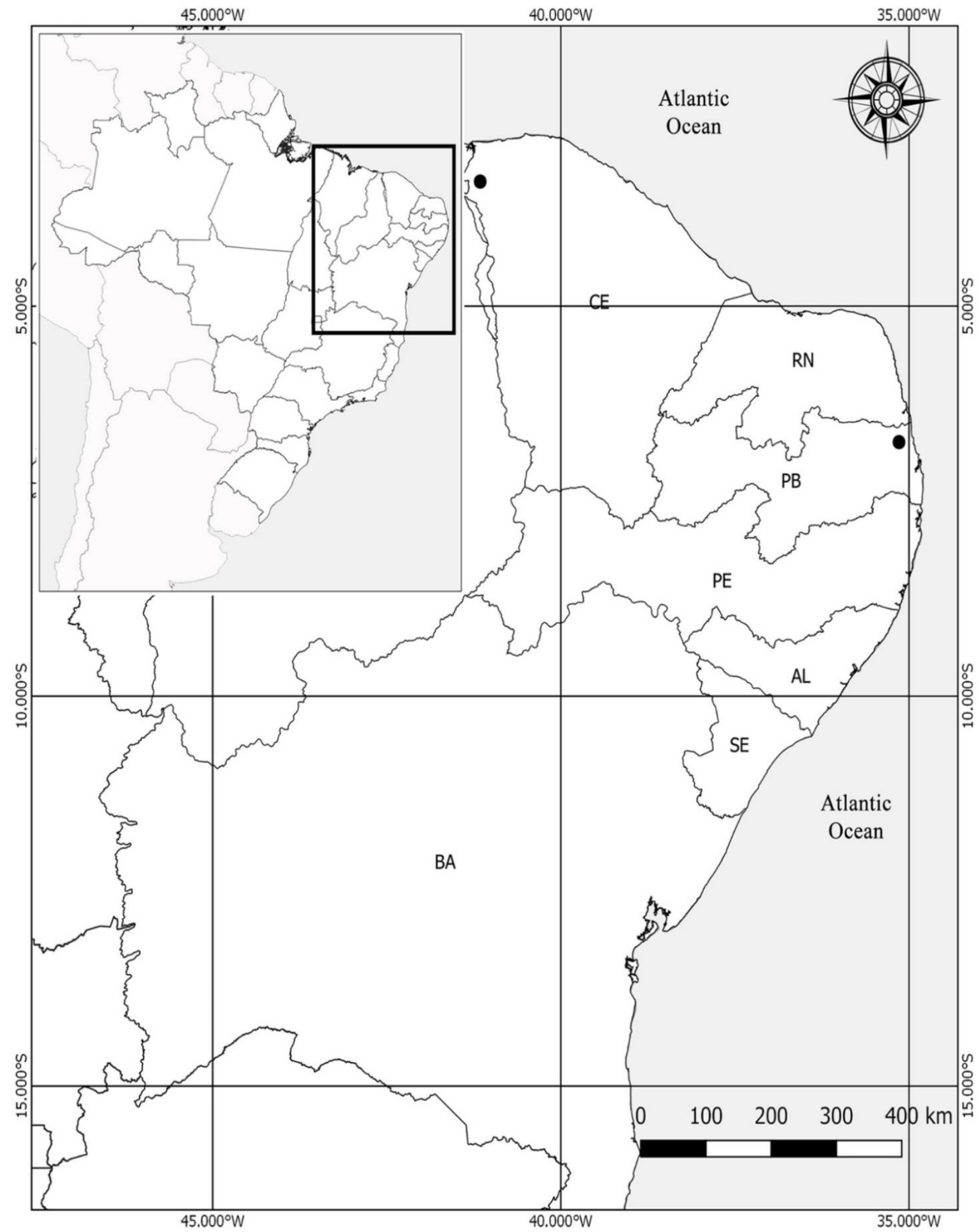

Projection: Universal Transverse Mercator. Coordinate System: Geographic Coordinates. Geodetic Datum: WGS 84. Date: JUN/2019

Figure 3. Distribution of Lacandonia brasiliana A. Melo and M. Alves (Triuridaceae) in Brazil: only in the Northeast region, one occurrence in Ceará (Viçosa do Ceará, Serra das Flores, 23.V.2019, Lucena et al. 666) and another in Paraíba (Mamanguape, Reserva Biológica de Guaribas, 25.IX.2010, Melo et al. 487). 
endemic species (Bordino, José Neto, \& Blini, 2018).

Lacandonia belongs to tribe Triurideae of the Triuridaceae and includes two species, Lacandonia schismatica E. Martínez \& Ramos and Lacandonia brasiliana A. Melo \& M. Alves, both endemic to the Neotropics. Lacandonia schismatica E. Martínez \& Ramos is known from the Lacandon region of Chiapas, Mexico (Martínez \& Ramos, 1989; Ambrose et al., 2006), whereas Lacandonia brasiliana A. Melo \& M. Alves, first described for South America by Melo and Alves (2012), was recorded for the Atlantic Forest in the State of Paraíba, Northeastern Brazil, ca. $20 \mathrm{~km}$ from the Atlantic coast, where the average annual temperature is $26^{\circ} \mathrm{C}$ and the annual rainfall 1,700 $\mathrm{mm}$. It grows in preserved protected forest areas in the moist decaying leaf litter on sandy soils and was collected fertile in August and September (Melo \& Alves, 2012). According to Rudall et al. (2016) the flowering period of Lacandonia schismatica E. Martínez \& Ramos occurs from November to December, thus occurring in the second half of the year. The appearance of Lacandonia brasiliana A. Melo \& M. Alves in Brazil didn't occur from a mutation of the species Lacandonia schismatica $\mathrm{E}$. Martínez \& Ramos, as the two species are considered evolutionarily close (Rudall et al., 2016).

Lacandonia is a genus with a disjunct distribution between the Mesoamerican forests of Chiapas, Mexico and the Atlantic Forest of Northeast Brazil. With this new occurrence, it brings subsidies on its evolution and distribution (Martínez \& Ramos, 1989; Melo \& Alves, 2012; Maas, Maas, \& Melo, 2015; Rudall et al., 2016). It belongs to the group of plants called mycoheterotrophs, or saprophytes, which convert organic matter with the aid of mycorrhizal fungi. Such an association can classify plants as total or initial mycoheterotrophic and partial or myxotrophic. The initial mycoheterotrophic only use the association of fungi only in the initial stage of their development, obtaining nutrients indirectly, whereas mixotrophic need the fungi more directly in the photosynthetic process (Mercks et al., 2013; Gebauer, Preiss, \& Gebauer, 2016; Jia, Nakano, Hattori, \& Nara, 2017). However, to date, it's not known whether Lacandonia brasiliana A. Melo \& M. Alves is initial mycoheterotrophic or myxotrophic.

According to Nuraliev, Kuznetsov, Kuznetsova and Averyanov (2019) nonphotosynthetic plants, as is the case with some representatives of mycoheterotrophs, present a notable number of species, producing little or no amount of chlorophyll, thus giving their whitish color, failing to carry out the process of photosynthesis thus differentiating it from autotrophic plants.

Their representatives in Brazil, from Gentianaceae, Triuridaceae, Burmanniaceae and Orchidaceae, all occur in its Northeast region (Melo \& Alves 2012; Melo \& Alves, 2013; Melo, Araújo, \& Alves, 2010, Ferreira et al., 2019).

In the Southeastern region, we have representatives from Burmanniaceae (Souza, Blum, \& Brotto, 2019), Thismiaceae (Guilherme, Coelho, Smidt, Gomes, \& Souza, 2016), Orchidaceae (Bittencourt \& Gasper, 2016; Mancinelli \& Quadros, 2016). In the South region we have studies with the family Triuridaceae (Valadares, Arçari, Martins, \& Schneider, 2015).

Such characteristics are also present in club mosses, liver (Marchantiophyta), gymnosperms (Lycopodiopsida and Polypodiopsida) (Mercks et al., 2012; Renny et al., 2017; Nuraliev et al., 2019), with about 20,000 species of plants (Mercks et al., 2013).

Scarcity of collectons of the mycoheterotrophic plants is due to the difficulty of their identification in the field (Santos, Barbosa, Santos, Bao, \& Rodrigues, 2013; Tsukaya \& Suetsugu, 2014;). Nevertheless, representatives of this little studied group continue to appear in herbarium collection databases around the world, especially in Brazil (Valadares et al., 2015).

The vast majority of mycoheterotrophic plants prefer extensive and well-preserved forest fragments, whether in temperate or tropical areas (Gomes, Bodegom, Merckx, \& Soudzilovskaia, 2019) and thus may be considered to be good bioindicator species (Melo et al., 2010).

\section{Conclusions}

Based on the results obtained, it can be concluded that:

1. The new occurrence of Lacandonia brasiliana A. Melo \& M. Alves for Ceará State, the second occurrence for Brazil and South America expanded its territorial distribution and the records of plant species that occur in the Cerrado of Ceará;

2. The importance of floristic surveys, in particular the forest remnants of the Cerrado in the State of Ceará, help to assess the degree of richness and conservation of their species, thus knowing the regional taxonomic flora.

3. Studies of new records involving mycoheterotrophic plants may provide subsidies 
for studies involving recovery of degraded areas since these species have preferences with a lot of nutrients and low anthropic action.

\section{Acknowledgements}

We are grateful to the Coordenação de Aperfeiçoamento de Pessoal de Nível Superior Brasil (CAPES, Finance Code 001) for granting the Master's Scholarship to the first author; to Maria Iracema Bezerra Loiola, curator of the Herbarium Prisco Bezerra (EAC) of the Federal University of Ceará, and to its personnel, Sarah Sued and Hugo Pereira, for their support and attention; to the State University of Ceara for the financial support of the fieldwork; to the residents and field guides of Serra das Flores who accompanied us during the expeditions.

\section{References}

Ambrose, B. A., Espinosa-Matias, S., VazquezSantana, S., Vergara-Silva, F., Martinez, E., Marquez-Guzman, J., \& Alvarez-Buylla, E. R. (2006). Comparative developmental series of the Mexican triurids support a euanthial interpretation for the unusual reproductive axes of Lacandonia schismatica (Triuridaceae). American Journal of Botany, 93(1), 15-35. doi:10.3732/ajb.93.1.15

Andrella, G. C., \& José Neto, M. (2017). Levantamento florístico dos arredores do parque das capivaras, Três Lagoas-MS. Revista Saúde e Meio Ambiente, 5(2), 70-77.

Angiosperm Phylogeny Group (APG). (2016). An update of the Angiosperm Phylogeny Group classification for the orders and families of flowering plants: APG IV. Botanical Journal of the Linnean Society, 181(1), 1-20. doi:10.1111/boj.12385

Bittencourt, F., \& Gasper, A. L. (2016). First record of Pogoniopsis Rchb. (Orchidaceae: Triphorinae) in Santa Catarina state, southern Brazil. Check List, 12(6) 1-5. doi:10.15560/12.6.1990

Bordino, L. F., Neto, M. J., \& Blini, R. C. B. (2018). Levantamento florístico de um fragmento de cerrado em recuperação no distrito industrial de Três Lagoas-MS. Revista Saúde e Meio Ambiente, 6(1), 45-55.

Cheek, M. (2003). Kupeaeae, a new tribe of Triuridaceae from Africa Kew. Bulletin, 58(4), 939-949. doi:10.2307/4111207

Christenhusz, M. J. M., \& Byng, J. W. (2016). The number of known plants species in the world and its annual increase. Phytotaxa, 261(3), 201. doi:10.11646/phytotaxa.261.3.1
Ferreira, A. W. C., Calió, M. F., Silva Júnior, W. R. S., Silva, M. J. C., Oliveira, M. S., Silva, E. O., . . Figueiredo, N. (2019). First record of Voyria caerulea Aubl. (Gentianaceae), a mycoheterotrophic plant, in Maranhão state, northeastern Brazil. Check List, 14(5), 833-837. doi:10.15560/14.5.833

Gebauer, G., Preiss, K., \& Gebauer, A. C. (2016). Partial mycoheterotrophy is more widespread among orchids than previously assumed. New Phytologist, 211(1), 11-15. doi:10.1111/nph.13865

Gomes, S. I. F., Bodegom, P. M., Merckx, V. S. T. F., \& Soudzilovskaia, N. A. (2019). Global distribution patterns of mycoheterotrophy. Global Ecology and Biogrography, 1(28), 1113-1145. doi:10.1111/geb.12920

Gonçalves, E. G., \& Lorenzi, H. (2011). Morfologia vegetal: organografia e dicionário ilustrado de morfologia das plantas vasculares (2a ed.). São Paulo: Instituto Plantarum.

Govaerts, R., Maas-van de Kamer, H., \& Maas, P. J. M. (2016). World checklist of Triuridaceae. Kew: Royal Botanic Gardens. Retrieved Mar 23, 2020, from http://apps.kew.org/wcsp/

Guilherme, F. A. G., Coelho, C. P., Smidt, E. C., Gomes, D. C., \& Souza, F. C. (2016). Thismia panamensis: first record of Thismiaceae for the Brazilian Cerrado in Goias state. Check List, 12(2), 1-4. doi:10.15560/12.2.1877

Instituto Brasileiro de Geografia e Estatística. (2012). Manual técnico da vegetação brasileira. ( $2 \mathrm{a}$ ed.). Rio de Janeiro: IBGE. Retrieved June 4, 2019, from http://geoftp.ibge.gov.br/documentos/recursos naturais/manuais_tecnicos/manual_tecnico_ve getacao_brasileira.pdf

Instituto de Pesquisa e Estratégia Econômica do Ceará. (2018). Perfil municipal 2017: Viçosa do Ceará. Fortaleza: IPECE. Retrieved May 25, 2019, from https://www.ipece.ce.gov.br/wpcontent/uploads/sites/45/2018/09/Vicosa_do_C eara_2017.pdf

Jia, S., Nakano, T., Hattori, M., \& Nara, K. (2017). Root-associated fungal communities in three Pyroleae species and their mycobiont sharing with surrounding trees in subalpine coniferous forests on Mount Fuji, Japan. Mycorrhiza, 27(8), 733-745. doi:10.1007/s00572-0170788-6

Maas H., Maas P., \& Melo, A. (2015). Triuridaceae in Lista de Espécies da Flora do Brasil. Rio de Janeiro: Jardim Botânico do Rio de Janeiro. Retrieved Mar 23, 2020, from http:// floradobrasil.jbrj.gov.br/ jabot/ floradobrasil/FB110684 
Maas, P. J. M., \& Rübsamen, T. (1986). Triuridaceae. Flora Neotropica Monograph, 40, 1-55.

Maas-Van de Kamer H., \& Weustenfeld, T. (1998). Triuridaceae. In K. Kubitzki (Ed.), The families and genera of vascular plants (vol. 3, pp. 452458). Berlin: Springer-Verlag.

Mancinelli, W. S., \& Quadros, K. E. (2016). Orchidaceae Flora of Joinville, Santa Catarina, Brazil. Acta Biológica Catarinense, 3(1), 36-48. doi:10.21726/abc.v3i1.231

Martínez, S. E. B., \& Ramos, C. H. (1989). Lacandoniaceae (Triuridales): una nueva familia de México. Annals of the Missouri Botanical Garden, 76(1), 128-135. doi:10.2307/2399346

Melo, A., \& Alves, M. (2012). The discovery of Lacandonia (Triuridaceae) in Brazil. Phytotaxa 40(1), 21-25. doi:10.11646/phytotaxa.40.1.3

Melo, A., \& Alves, M. (2013). Sinopse das ervas aclorofiladas ocorrentes no norte da Floresta Atlântica, Brasil. Revista Brasileira de Biociências, 11(1), 29-38.

Melo, A., Araújo, A., \& Alves. M., 2010. Burmanniaceae e Gentianaceae da Usina São José, Igarassu, Pernambuco. Rodriguésia, 61(3), 431-440. doi:10.1590/21757860201061307

Mennes, C. B., Smets, E. F., Moses, S. N., \& Merckx, V. S. R. T. (2013). New insights in the long-debated evolutionary history of Triuridaceae (Pandanales). Molecular Phylogenetics and Evolution, 69, 994-1004. doi:10.1016/j.ympev.2013.05.03

Merckx, V. S. F. T., Freudenstein, J. V., Kissling, J., Christenhusz, M. J. M., Stotler, R. E., Crandall-Stotler, B., . . . Maas, P. J. M. (2013). Taxonomy and classification. In V. S. F. T. Merckx (Ed.), Mycoheterotrophy: The biology of plants living on fungi. (1a ed., Cap. 1-3, pp. 1-156). New York: Springer Science Business Media. doi:10.1007/978-1-4614-5209-6_2

Merckx, V. S. F. T., Janssens, S. B., Hynson, N. A., Specht, C. D., Bruns, T. D., \& Smets, E. F. (2012). Mycoheterotrophic interactions are not limited to a narrow phylogenetic range of arbuscular mycorrhizal fungi. Molecular Ecology, 21(6), 1524-1532. doi:10.1111/j.1365-294x.2012.05472.x

Mori, S. A., Silva, L. A. M., Lisboa, G., \& Coradin, L. (1989). Manual de manejo do herbário fanerogâmico (2a ed.). Ilhéus: Centro de Pesquisa do Cacau.

Nuraliev, M. S., Cheek, M. R., \& Beer, A. S. (2016). Seychellaria barbata (Triuridaceae), a new species from Marojejy National Park,
Madagascar. Phytotaxa, 268, 229-243. doi:10.11646/phytotaxa.268.4.1-

Nuraliev, M. S., Kuznetsov, A. N., Kuznetsova, S. P., \& Averyanov, L. V. (2019). Towards inventory of non-photosynthetic plants in Vietnam: a progress report. Wulfenia, 26(1), 147-154.

Radford, A. E., Dickison, W. C., Massey, J. R., \& Bell, C. R. (1974). Vascular Plant Systematics (1a ed.). New York: Harper \& Row Publishers.

Renny, M., Acosta, M. C., Cofré, N., Domínguez, L. S., Bidartondo, M. I., \& Sérsic, A. N. (2017). Genetic diversity patterns of arbuscular mycorrhizal fungi associated with the mycoheterotroph Arachnitis uniflora Phil. (Corsiaceae). Annals of Botany, 119(8), 12791294. doi:10.1093/aob/mcx023

Ribeiro, J. F., \& Walter, B. M. T. (1998). Fitofisionomias do Bioma Cerrado. In S.M Sano, \& S.P Almeida (Eds.) Cerrado: ambiente e flora (1a ed., Cap. 3, pp. 89-166). Planaltina: EMBRAPA/CPAC.

Rudall, P. J., Alves, M., \& Sajo, M. G. (2016). Inside-out flowers of Lacandonia brasiliana (Triuridaceae) provide new insights into fundamental aspects of floral patterning. Peerj, 4(1), 16-53. doi:10.7717/peerj.1653

Santos, V. M. C., Barbosa, L., Santos, Q. C., Bao, F., \& Rodrigues, D. (2013). New records of Sciaphila Blume, Sciaphila purpurea Benth; Triuris Miers and Triuris hyaline Miers in the Southern Amazon forest, Mato Grosso, Brazil. Check List, 9(4), 867-869. doi:10.15560/9.4.867

Sochor, M., Hroneš, M., \& Dančák, M. (2018). New insights into variation, evolution and taxonomy of fairy lanterns (Thismia, Thismiaceae) with four new species from Borneo. Plant Systematics and evolution, 304(5), 699-721. doi:10.1007/s00606-0181504-5

Souza, I., Blum, C.T., \& Brotto, M.L. (2019). First record of Gymnosiphon tenellus (Benth.) Urb. (Burmanniaceae) in Paraná state and Southern Brazil. Check list, 15(5), 863-866. doi:10.15560/15.5.863

Souza, V.C., \& Lorenzi, H. (2019). Botânica Sistemática: guia ilustrado para identificação das famílias de fanerógamas nativas e exóticas no Brasil, baseado em APG IV. (4a ed.). Nova Odessa: Jardim Botânico Plantarum.

Strassburg, B. B. N., Brooks, T.; Feltran-Barbieri, R., Iribarrem, A., Crouzeilles, R., Loyola, R., . . . Balmford, A. (2017). Moment of truth for the Cerrado hotspot. Nature Ecology \& Evolution, 1(4), 1-3. doi:10.1038/s41559-017-0099 
Suetsugu, K., Naiki, A., Takeuchi, Y., Toyama, H., Tagane, S., \& Yahara, T. (2017). New Distributional Records of the Mycoheterotrophic Sciaphila alba (Triuridaceae), outside the Type Locality. Acta Phytotaxonomica Geobotanica, 68(2), 123126. doi:10.18942/apg.201614

The Brazil Flora Group. (2018). Brazilian Flora 2020: innovation and collaboration to meet Target 1 of the Global Strategy for Plant Conservation (GSPC). Rodriguésia, 69(4), 1513-1527. doi:10.1590/2175-7860201566411

Thiers, B. (2019). Index Herbariorum: a global directory of public herbaria and associated staff. New York: New York Botanical Garden's Virtual Herbarium. Retrieved June 1, 2019, from http://sweetgum.nybg. org/science/ih/
Tsukaya, H., \& Okada, H. (2013). Two new species of Sciaphila Blume (Triuridaceae) from Kalimantan, Borneo, with a new record of $S$. thaidanica from Borneo. Systematic Botany, 38(3),

600-605. doi: $10.1600 / 036364413 \times 670476$

Tsukaya, H., \& Suetsugu, K. (2014). Two new species of Sciaphila (Triuridaceae) from Sarawak (Borneo, Malaysia). Phytotaxa, 170(4), 283-290. doi:10.11646/phytotaxa.170.4.6

Valadares, R. T., Arçari, F. S. S., Martins, M. L. L., \& Schneider, S. Z. (2015). Ocorrência de Sciaphila purpurea Benth (Triuridaceae) em Restinga do Estado do Espírito Santo, Brasil. Boletim do Museu de Biologia Mello leitão, 37(1), 19-27. 